\title{
Advances on the Influence of Vegetation and Forest on Urban Air Quality and Thermal Comfort
}

\author{
Jose-Luis Santiago *(D) and Esther Rivas \\ Atmospheric Pollution Division, Environmental Department, CIEMAT, Av Complutense 40, 28040 Madrid, Spain; \\ esther.rivas@ciemat.es \\ * Correspondence: jl.santiago@ciemat.es
}

check for updates

Citation: Santiago, J.-L.; Rivas, E. Advances on the Influence of Vegetation and Forest on Urban Air Quality and Thermal Comfort. Forests 2021, 12, 1133. https://doi.org/ 10.3390/f12081133

Received: 17 August 2021

Accepted: 20 August 2021

Published: 23 August 2021

Publisher's Note: MDPI stays neutral with regard to jurisdictional claims in published maps and institutional affiliations.

Copyright: (c) 2021 by the authors. Licensee MDPI, Basel, Switzerland. This article is an open access article distributed under the terms and conditions of the Creative Commons Attribution (CC BY) license (https:// creativecommons.org/licenses/by/ $4.0 /)$.
The interactions between the atmosphere and urban obstacles such as buildings or vegetation induce complex flow patterns because of the heterogeneities of urban morphology. Street ventilation is reduced and this fact, linked with the large pollutant emissions from vehicles, gives rise to high pollutant concentrations $\left(\mathrm{NO}_{2}, \mathrm{PM}_{10}, \mathrm{PM}_{2.5}\right.$, etc. $)$ and strong gradients of concentration within streets. In addition, the thermal and optical properties of the materials determine the heat exchange between urban surfaces and the atmosphere. Typical construction materials in cities (brick, glass, etc. in buildings and asphalt in roads) and morphology of urban areas (buildings that form streets) often increase the air temperature and cause thermal discomfort in urban environments. Considering that most people live in cities, a high percentage of the population is exposed to these climate conditions and air pollution problems. Therefore, mitigation strategies are necessary to improve thermal comfort and air quality in urban environments. Due to the regulating services provided by urban vegetation, one of the main strategies employed in different cities is the use of green infrastructures. The main regulating services and disservices provided are microclimate regulation, variation of pollutant dispersion, absorption and deposition of pollutants, emission of biogenic volatile compounds, pollen released and noise attenuation [1-4].

Atmosphere-urban vegetation interaction is complex and a careful design of green infrastructure is needed. The main effects of urban vegetation on air quality are:

- $\quad$ Aerodynamic effects: Trees and hedgerows are porous obstacles and wind flow and turbulence are modified around them, and consequently, pollutant dispersion is also changed.

- Deposition effects: vegetation removes a fraction of pollutants from the air through deposition on leaves and absorption through stomata.

Deposition effects on air quality are always positive, however, aerodynamic effects can be positive or negative depending on green infrastructure and urban environment configurations. For instance, aerodynamic effects of vegetation barriers in open roads contribute to improving air quality behind the barrier [5-8]. However, street trees can reduce street ventilation and increase pollutant concentration at the pedestrian level [9-11]. The main thermal effects of urban vegetation are due to a combination of evapotranspiration and shading (cooling effect). Tree shading prevents the rise of surface temperature and significantly reduces the mean radiant temperature in the pedestrian zones because trees intercept solar radiation. In addition, urban vegetation provides transpirational cooling because they transform some of the absorbed solar energy into latent heat (water from vegetation is evaporated), causing the cooling of leaf surfaces and thus the surrounding air. The effectiveness of nature-based solutions to improve thermal comfort depends on several factors such as the configuration of urban environments and the involved green infrastructure $[1,2,12,13]$.

More knowledge about the complex effects of different types of green infrastructures on air quality and thermal comfort is needed to design effective strategies for renaturing 
urban environments. Taking into account this context, original research articles relating to the impact of urban vegetation on air quality and local climate in urban environments are welcomed to the current Special Issue entitled "Advances on the Influence of Vegetation and Forest on Urban Air Quality and Thermal Comfort". These contributions can address modeling studies at micro- and/or meso-scale (e.g., computational fluid dynamics models, urban canopy models or mesoscale models), new parameterizations on the effects of urban vegetation and/or experimental works from field and laboratory experiments. Urban green infrastructures such as different configurations of trees in the streets, urban parks or vegetation barriers will be investigated in relation to their effects on pollutant concentration (aerodynamic effects, pollutant deposition, biogenic emissions like pollen, etc.) and/or on local climate and thermal comfort (transpirational cooling, shading, etc.). In addition, review papers focused on the current knowledge and future studies about this topic are also welcomed to the current Special Issue.

Author Contributions: Conceptualization, J.-L.S. and E.R.; methodology, J.-L.S. and E.R.; writingoriginal draft preparation, J.-L.S. and E.R.; writing-review and editing, J.-L.S. and E.R. All authors have read and agreed to the published version of the manuscript.

Funding: This research was funded by the National Agency for Scientific Research of the Spanish Ministry of Science and Innovation through the RETOS-AIRE (Air pollution mitigation actions for environmental policy support. Air quality multiscale modeling and evaluation of health and vegetation impacts) project with grant number RTI2018-099138-B-I00.

Data Availability Statement: Not applicable.

Conflicts of Interest: The authors declare no conflict of interest.

\section{References}

1. Salmond, J.A.; Tadaki, M.; Vardoulakis, S.; Arbuthnott, K.; Coutts, A.; Demuzere, M.; Dirks, K.N.; Heaviside, C.; Lim, S.; Macintyre, H. Health and climate related ecosystem services provided by street trees in the urban environment. Environ. Health 2016, 15, 95-111. [CrossRef] [PubMed]

2. Santamouris, M.; Ban-Weiss, G.; Osmond, P.; Paolini, R.; Synnefa, A.; Cartalis, C.; Muscio, A.; Zinzi, M.; Morakinyo, T.E.; Ng, E.; et al. Progress in urban greenery mitigation science-assessment methodologies advanced technologies and impact on cities. J. Civ. Eng. Manag. 2018, 24, 638-671. [CrossRef]

3. Abhijith, K.V.; Kumar, P.; Gallagher, J.; McNabola, A.; Baldauf, R.; Pilla, F.; Broderick, B.; Di Sabatino, S.; Pulvirenti, B. Air pollution abatement performances of green infrastructure in open road and built-up street canyon environments-A review. Atmos. Environ. 2017, 162, 71-86. [CrossRef]

4. Buccolieri, R.; Santiago, J.L.; Rivas, E.; Sanchez, B. Review on urban tree modelling in CFD simulations: Aerodynamic, deposition and thermal effects. Urban For. Urban Green. 2018, 31, 212-220. [CrossRef]

5. Santiago, J.L.; Buccolieri, R.; Rivas, E.; Calvete-Sogo, H.; Sanchez, B.; Martilli, A.; Alonso, R.; Elustondo, D.; Santamaría, J.M.; Martin, F. CFD modelling of vegetation barrier effects on the reduction of traffic-related pollutant concentration in an avenue of Pamplona, Spain. Sustain. Cities Soc. 2019, 48, 101559. [CrossRef]

6. Abhijith, V.; Kumar, P. Field investigations for evaluating green infrastructure effects on air quality in open-road conditions. Atmos. Environ. 2019, 201, 132-147. [CrossRef]

7. Gallagher, J.; Baldauf, R.; Fuller, C.H.; Kumar, P.; Gill, L.W.; McNabola, A. Passive methods for improving air quality in the built environment: A review of porous and solid barriers. Atmos. Environ. 2015, 120, 61-70. [CrossRef]

8. Wang, H.; Maher, B.A.; Ahmed, I.A.; Davison, B. Efficient removal of ultrafine particles from diesel exhaust by selected tree species: Implications for roadside planting for improving the quality of urban air. Environ. Sci. Technol. 2019, 53, 6906-6916. [CrossRef] [PubMed]

9. Santiago, J.-L.; Rivas, E.; Sanchez, B.; Buccolieri, R.; Martin, F. The Impact of Planting Trees on NOx Concentrations: The Case of the Plaza de la Cruz Neighborhood in Pamplona (Spain). Atmosphere 2017, 8, 131. [CrossRef]

10. Vranckx, S.; Vos, P.; Maiheu, B.; Janssen, S. Impact of trees on pollutant dispersion in street canyons: A numerical study of the annual average effects in Antwerp. Belgium. Sci. Total Environ. 2015, 532, 474-483. [CrossRef] [PubMed]

11. Gromke, C.; Blocken, B. Influence of avenue-trees on air quality at the urban neighborhood scale. Part II: Traffic pollutant concentrations at pedestrian level. Environ. Pollut. 2015, 196, 176-184. [CrossRef] [PubMed] 
12. Gatto, E.; Buccolieri, R.; Aarrevaara, E.; Ippolito, F.; Emmanuel, R.; Perronace, L.; Santiago, J.L. Impact of Urban Vegetation on Outdoor Thermal Comfort: Comparison between a Mediterranean City (Lecce, Italy) and a Northern European City (Lahti, Finland). Forests 2020, 11, 228. [CrossRef]

13. Gatto, E.; Ippolito, F.; Rispoli, G.; Carlo, O.S.; Santiago, J.L.; Aarrevaara, E.; Emmanuel, R.; Buccolieri, R. Analysis of Urban Greening Scenarios for Improving Outdoor Thermal Comfort in Neighbourhoods of Lecce (Southern Italy). Climate 2021, 9, 116. [CrossRef] 